\title{
An overview of encouraging sustainable tourism in the coastal tourism of Karang Jahe beach: issues and challenges
}

\author{
Julita Budi Prasetyo ${ }^{1, *}$, Fuad Muhammad ${ }^{2}$, and Denny Nugroho Sugianto ${ }^{3,4}$ \\ ${ }^{1}$ Magister Programme of Environmental Science, School of Postgraduate Studies, Diponegoro University, Semarang - Indonesia \\ ${ }^{2}$ Department of Biology, Faculty of Science and Mathematics, Diponegoro University, Semarang - Indonesia \\ ${ }^{3}$ Department of Oceanography, Faculty of Fisheries and Marine Science, Diponegoro University, Semarang - Indonesia \\ ${ }^{4}$ Center for Coastal Disaster Mitigation and Rehabilitation Studies. Diponegoro University - Indonesia
}

\begin{abstract}
Sustainable tourism basically governs human and environmental relations based on the principles of sustainable development. Thus the critical challenge for policy-makers is how to ensure sustainability, quality and human and environmental issues in the tourism sector. Tourism Area of Karang Jahe Beach (KJB) according to Plan of Utilization of WP3K Spatial Allocation of Central Java Province is included in tourism zone. The growth of nature tourism in this area is quite rapid over the last three years with the typology of mass tourism. The growth of nature-based tourism activities encourages economic growth and the welfare of the people. But in its implementation, nature tourism activities become very susceptible to interference due to human intervention. Considering the ecosystem's richness in the coastal area, the economic potential and the complexity of tourism management in coastal areas, the planning of sustainable tourism development should be a serious concern of stakeholders, including coastal tourism in Karang Jahe Beach. The relevance of sustainable tourism development planning in Karang Jahe Beach can be seen from several issues 1) economic, 2) social, 3) environment and 4) legal. A Touristic Ecological Footprint can be used as an approach to assess the environmental carrying capacity and formulate a coastal tourism development strategy. Carrying capacity-based ecotourism development is expected to play an important role in realizing low carbon community development..
\end{abstract}

Keywords: Carrying Capacity; Coastal tourism; Sustainable Development; Sustainable Tourism

\section{Introduction}

The travel and tourism industries growth faster in the world and is a source of income for many developing countries. This industry is responsible for over 230 million jobs and over $10 \%$ of the gross domestic product (GDP) worldwide. [1]. Globally, this sector contributes positively to the level of GDP (Gross Domestic Product) and employment [2], including in Indonesia [3]. The significant growth in tourism over the last three decades has led to increasing the relationship between the tourism and the environment. The interaction between tourism and efforts to conserve natural resources has been the concern of experts for the last 3 (three) decades which then led to the phenomenon of ecotourism, which is grew faster than the tourism industry as a whole. The United Nations Environment Program (UNEP) and the Conservation International agency indicate that most of the tourism expansion is happening and around the world's remaining natural areas [1], including Indonesia.
As one of the largest archipelagic countries, coastal tourism becomes one of potential alternative that can be developed. In 2002, the Government of Indonesia has launched an ecotourism program and Year 2003 is designated as the year of maritime tourism. Coastal areas have biodiversity, resource productivity and environmental services and accessibility. In these conditions, coastal areas find their relevance as a potential place for the development of various intensive development activities, including the development of nature-based tourism. However, on the other hand, it is also very vulnerable to various forms of negative impacts caused by development activities both within the coastal areas and those on the upper and the high seas. Nature based tourism is defined, as a form of tourism that includes forms of tourism (eg, mass tourism, low impact tourism, adventure tourism and ecotourism) that use wild or underdeveloped natural resources. A complex set of social, economic, physical and ecological relationships in different settings has increased the understanding that

\footnotetext{
* Corresponding author: arjunarimba77.bp@gmail.com
} 
ecotourism plays an important role in realizing sustainable tourism. In many ways, sustainable tourism illustrates the important role of cotourism to the sustainable development. Thus, the fundamental and critical challenge for the coastal area planners and managers is how to facilitate economic development, while minimizing the negative impacts of development activities in accordance with the carrying capacity of the coastal environment. Sustainable tourism must play an important role in realizing low carbon community development.

\section{The challenge to achieve sustainable tourism}

\subsection{Human aspect}

In the human aspect, the issues of sustainable tourism is concerned with :

1. Gender equality;

The challenge of sustainable tourism development is one of them is about gender equality. Research [4] found that in terms of formal employment and decision making, local women are often ignored. In some cases, women even fall into prostitution activities around the tourist area. So the critical challenge is to ensure that women get a decent portion of their livelihoods and decision-making in development activities.

2. Political-economy policy;

One of the main issues is the compatibility of sustainable tourism to economic growth. Economic growth is about increasing the production and consumption of goods and services. Economic growth is often accompanied by a decline in natural resources. Sustainable tourism must be understood from the perspective that economic development, including tourism, depends on the stock of natural capital. Tourism steady-state is a tourism system capable of encouraging the improvement of the quality of life and human welfare without harming natural capital [5].

3. Capacity and capability of communities; and Ecotourism, in principle, should empower local communities. The Quebec Declaration in 2002 [6], suggest that 5 (five) criterias should be used to define ecotourism: nature-based products, minimal impact management, environmental education, contribution to conservation and community.

Community Based Tourism (CBT) Management is an alternative to rural community economic activities other than agriculture and natural resource use. CBT is useful to equate people's perceptions and visions in tourism development to reduce potential conflicts and misunderstandings in the future. Second, to provide a good understanding of the positive and negative effects of CBT. Third, gain a more detailed understanding of the similarities and differences between tourists and community members from the local context, including the motivation to travel. Knowledge gained by the community, from these experiences, then becomes a learning tools in decision-making to achieve their ideals, values and interests in the tourism planning process [7].

To improve community capacity, it is necessary to provide assistance and partnership efforts. Governments, financial institutions (banks), environmental NGOs and eco-tourism consulting companies channel financial and technical resources to local communities in the hope that ecotourism can be a tool for integrated conservation and development. This partnership allows people with no experience in tourism to participate and benefit from ecotourism [8].

\subsection{Environmental aspect}

In the environmental aspect, the issues of sustainable tourism is concerned with:

1. Climate Change

Tourism can not be separated from the global response to climate change. There is a causal-loop between tourism and global warming, both as victims and contributor. The rise of sea level, desertification and water scarcity, deforestation and threats to biodiversity caused by global warming, as well as melting of snow and glaciers. These conditions make the tourism sector as a victim of global warming. On the other hand, tourism also contributes to global warming, although there is no precise calculation yet. Tourism contributes to global $\mathrm{CO}_{2}$ emissions and global warming, about $5 \%$ and $4,6 \%$ respectively. The air transportation sector became a major tourism contributor to global warming. This sector is responsible for total carbon emissions due to tourism sector, and from radiation transmitters $40 \%$ and $54-75 \%$ respectively [9].

Coastal tourism becomes a "victim" that must be prioritized, as coastal areas are particularly vulnerable to climate change. A studies suggest that climate change can be assessed first through changes in physical conditions necessary for tourism; second, by using climate index to measure tourist attraction; and, thirdly, by modeling the demand for tourism by incorporating climatedetermining factors [10] .

2. Land Use-Land Cover Change (LULCC)

Tourism development requires access to land. Land is required for tourism infrastructure and facilities as well as tourism-related businesses and services. An LUCC modeling was developed to determine the impact of tourism development on built-up areas by considering the suitability of land cover and the proposed proximity of development to the coastline. The simulation results show that scenarios based on tourism trends indicate that tourism growth and urban land cover changes are higher and highly focused in coastal 
areas (within 5,000m) [11]. Similar research in China's special economic zone, Hainan indicated tourism-influenced developments have led to landscape fragmentation, vegetation degeneration, coastal erosion [12], quantitatively, increase in demand for construction land and sustainable spatial disturbance with landscapes [13].

3. Spatial Planning

Spatial planning and tourism relate to one another. Spatially, tourism occupies a certain place with distinctive spatial character. Spatial planning acts as a tool to integrate the various interests of land use in a region. Sustainability is a complex issue and has many factors (social, economic, cultural and environmental), so it is difficult to ensure sustainability without a true and consistent spatial approach [14]. The challenge of spatial planning is to ensure an efficient utilization of limited land resources and to ensure equitable use of resources for development activities, including natural resources and landscape, land, water and air resources. The issue of sustainable tourism can not be separated from spatial planning. Policy-makers should consider the area suitability aspect with spatial planning in developing sustainable tourism [15].

4. Carrying Capacity

In the context of tourism, carrying capacity can be described as the maximum number of people who can visit tourist destinations at the same time, without causing damage to the physical, economic and socio cultural environments and degrading the quality of unacceptable visitor satisfaction [16]. One approach to determining environmental carrying capacity is the Ecological Footprint (EF) analysis. Ecological footprint is a regional-based indicator that quantifies the intensity of human

resource use and waste disposal activities in relation to the ecological carrying capacity of a region [17]. The main strengths of ecological footprint analysis because it involves ecological economics considerations in its analysis [18] .

The eco-footprint analysis of tourism is one of the newest and most effective methods used to analyze the environmental impact of tourism. Tourism is a dynamic activity where every visitor has different consumption activities and behaviors. A study has shown that a) tourism is a type of lifestyle with extreme ecological consumption, where EF per capita produced by tourists is greater than the EF of local people generated from their daily lives in tourism and tourist destinations, b) by approach components, EF's most important tourism components are transportation, accommodation, food and waste [19].

\section{Apllying sustainable tourism in Karangjahe Beach}

Considering the ecosystem's richness in the coastal area, the economical potention and the complexity of tourism management in coastal areas, the planning of sustainable tourism development should be a serious concern of stakeholders, including coastal tourism in Karang Jahe Beach (KJB). Geographically, Pantai Karang Jahe is located in Rembang regency, which is one of the regencies in the north coast of Central Java Province. The relevance of sustainable tourism development planning in $\mathrm{KJB}$ can be seen from several issues:

1. Economy

From economic aspect, the research by [20] mentioned that the potential of economic value of intangible tourism at KJB is Rp 305 billion per year with actual utilization rate of $\mathrm{Rp} 26$ billion per year $(8,6 \%$ from economic potency). The same study shows that surplus value of KJB ecotourism consumers is greater than the actual average cost incurred by visitors. This indicates that visitors benefit from environmental services greater than the cost incurred. The greater economical potention value must be accompanied by efforts to maintain the quality of the environment.

2. Social

From the social aspect, its relevance can be seen from the involvement of the community in managing the coastal tourism of Karang Jahe Beach. The establishment of KJB Management Board is one of the efforts to encourage the development of ecotourism in the region. In addition to synchronize with village development activities then formed a village-owned enterprise. The data from the KJB Management Board said that the implementation of coastal tourism has absorbed 500 more labor.

3. Environment

From the environmental aspect, the carrying capacity of the area as a result of the increasing number of visits should be the attention of the KJB Management Board. The growth of nature tourism in this area is quite rapidly during the last three years with the typology of mass tourism. The average of visits during the Year 2015-2017 increased from 939 persons/day, 1,900 persons/day to 2,761 persons/day, respectively. These conditions must be serious attention for the KJB Management Board. Tourism influences local social and cultural structures, economics and land use in local communities. In addition, tourism also causes pressure on the natural environments.

4. Legal

From the legal aspect, coastal tourism development of KJB must be in accordance with the direction of regional planning. According to the Plan of Zoning of Coastal Areas and Small Islands (RZWP3K) of Central Java Province in 2017-2037, this region includes tourism sub zone 
of coastal/coastal tourism zone [21]. According to Local Regulation No. 14 of 2011 on Spatial Planning of Rembang Regency Year 2011-2031, one of the potential development strategies of marine and fishery sector in the north is developing an integrated coastal tourism area. KJB tourism area located in District Rembang, including into seafront city. This area is a manifestation of coastal area management into a leading coastal city area through the development of activity centers and network of road transport and marine transportation infrastructure in the integration of the development of tourism area, fishery area and industrial area of Rembang Regency [22].

Another challenge of the legal aspect is the possibility of a conflict of norms between Law No. 23/2014 on Regional Government and Law No. $1 / 2014$ on the Amendement of Law Number 27/2007 on the Management of Coastal Areas and Small Islands. One of the implications of Law No $23 / 2014$ is that the law does not entirely authorize or reduce the authority of resource management in marine, coastal and small islands areas of the Regency/City. This resulted in a lack of clarity of interpretation of the regulation [23]. In 2017, the village government of Punjulharjo has issued Village Regulation No $1 / 2017$ as a legal standing for managing Karangjahe beach tourism objects.

\section{Conclusions}

The fundamental and critical challenge to establish sustainable tourism is how to facilitate economic development, while minimizing the negative impacts of development activities in accordance with the carrying capacity of the coastal environment. A complex set of social, economic, physical and ecological relationships in different settings has increased the understanding that ecotourism plays an important role in realizing sustainable tourism. In many ways, sustainable tourism illustrates the important role of cotourism to the sustainable development.

Sustainable tourism basically regulates human and environmental relations according to the principles of sustainable development. Thus the critical challenge for policymakers is how to ensure sustainability, quality and human and environmental issues in the tourism sector. From the human aspect, the issue of sustainable tourism is linked to gender equality, economic policy politics and capacity and capability of society. While from the environmental aspect, the issues of sustainable tourism concern with climate change, land use and land cover change, spatial planning and carrying capacity. Considering the ecosystem's richness in the coastal area, the economic potential and the complexity of tourism management in coastal areas, the planning of sustainable tourism development should be a serious concern of stakeholders, including coastal tourism in KJB. The relevance of sustainable tourism development planning in Karang Jahe Beach can be seen from several perspectives
1) economic, 2) social, 3) environment and 4) legal. A Touristic Ecological Footprint can be used as an approach to assess the environmental carrying capacity and formulate a coastal tourism development strategy. Carrying capacity-based ecotourism development is expected to play an important role in realizing low carbon community development.

\section{References}

1 TIES, "TIES Global Ecotourism Fact Sheet," Washington, (2006).

2 WTTC, "Travel \& Tourism Economic Impact 2017: World," London, (2017).

3 WTTC, “Travel \& Tourism Economic Impact 2017: Indonesia,” London, (2017).

4 M. Das and B. Chatterjee, "Ecotourism: A panacea or a predicament?," Tour. Manag. Perspect., vol. 14, pp. 3-16, (2015).

5 C. M. Hall, "Degrowing Tourism: Décroissance , Sustainable Consumption and Steady State Tourism," Anatolia An Int. J. Tour. Hosp. Res., vol. 20:1, pp. 46-61, (2009).

UNEP/WTO, "World Ecotourism Summit 2002," Canada, (2002).

7 J. Sammy, "Examples of Effective Techniques for Enhancing Community Understanding of Tourism," in Building Community Capacity for Tourism Development, G. Moscardo, Ed. Oxfordshire-UK: CABI Publishing, pp. 7585,(2008).

8 A. Stronza, "Partnership for Tourism Development," in Building Community Capacity for Tourism Development, G. Moscardo, Ed. Oxfordshire-UK: CABI Publishing, pp. 101-115, (2008).

9 UNWTO, "FAQ Climate Change and Tourism," http://sdt.unwto.org/content/faqclimate-change-and-tourism, (d.a) .

10 J. Rosselló-nadal, "How to evaluate the effects of climate change on tourism," Tour. Manag., vol. 42, pp. 334-340, 2014.

11 I. Boavida Portugal, J. Rocha, and C. C. Ferreira, "Exploring the impacts of future tourism development on land use/cover changes," Appl. Geogr., vol. 77, pp. 82-91, (2016).

12 J. Wang and Y. Liu, "Tourism-Led Land-Use Changes and their Environmental Effects in the Southern Coastal Region of Hainan Island , China," J. Coast. Res., vol. 29, no. 5, pp. 11181126, 2013.

13 X. Mao, J. Meng, and Q. Wang, "Land Use Policy Modeling the effects of tourism and land regulation on land-use change in tourist regions: A case study of the Lijiang River Basin in," Land use policy, vol. 41, pp. 368-377, (2014).

14 O. M. Dede and M. Ayten, "The role of spatial planning for sustainable tourism development: 
A theoretical model for Turkey," Tourism, vol. 60, no. 4, pp. 431-445, (2012).

15 M. Risteski, J. Kocevski, and K. Arnaudov, "Spatial planning and sustainable tourism as basis for developing competitive tourist desti nations," Procedia - Soc. Behav. Sci., vol. 44, pp. 375-386, (2012).

16 PAP/RAC, Guidelines for Carrying Capacity Assessment for Tourism in.Mediterranean Coastal Areas, $\quad$ PAP-9/1997. Split: Priority Actions Programme Regional Activity Centre, (1997).

17 M. Wackernagel and J. D. Yount, "The Ecological Footprint: an Indicator of Progress Toward Regional Sustainability," Environ. Monit. Assessment1, vol. 51, pp. 511-529, (1998).

18 W. E. Rees, "Eco-footprint analysis: Merits and brickbats," Ecol. Econ., vol. 32, no. 3, pp. 371374, (2000).
19 L. Peng and Y. Guihua, "Ecological footprint study on tourism itinerary products in ShangriLa, Yunnan Province, China," Acta Ecol. Sin., vol. 27, no. 7, pp. 2954-2963, (2007).

20 R. F. Abdillah, "Penilaian Manfaat Ekonomi dan Pengelolaan Lingkungan Wisata Pantai Karangjahe Kabupaten Rembang," Universitas Diponegoro, (2017).

21 Marine and Fishery Office, "Zoning Planning Coastal Areas and Small Islands of Central Java Province," Semarang, (2017).

22 Bupati Rembang, Rencana Tata Ruang Wilayah Kabupaten Rembang Tahun 2011-2031. Regional Secretariat of Rembang Regency, (2011).

23 R. Simarmata and A. Y. Firdaus, Pemberlakuan UU No 23/2014 dan Desentralisasi: Kajian di Bidang Pengelolaan Sumber Daya Alam. Jakarta, (2016). 